\title{
TINJAUAN TEOLOGIS: ALLAH MENYESAL BERDASARKAN PERSPEKTIF KITAB KEJADIAN PASAL 6:6-7
}

\author{
Yetris Elbaar $^{1}$ \\ Peniel Maiaweng ${ }^{2}$ \\ peniel_68@yahoo.com
}

\begin{abstract}
ABSTRAK
Tujuan penelitian ini adalah Pertama, untuk menjelaskan makna Allah menyesal melalui pemaparan eksposisi nas di dalam kitab Kejadian 6:6-7, supaya dapat menghasilkan kerangka pemahaman yang benar tentang Allah sebagai Pencipta. Kedua, untuk mendapatkan pemahaman yang benar mengenai Allah menyesal berdasarkan penjelasan implikasi teologis. Ketiga, supaya orang percaya dapat mengerti makna mengenai Allah menyesal dalam kitab Kejadian 6:6-7 yang dijabarkan dalam implikasi praktis.

Penulisan karya ilmiah ini menggunakan metodologi eksposisi, dengan menggunakan prinsip-prinsip hermeneutika, yaitu dengan kajian eksegesis Alkitab mengenai Allah menyesal berdasarkan Kejadian 6:6-7 dan melalui penelitian kualitatif, yaitu dengan penggunaan buku-buku di perpustakaan yang berkaitan dengan konsep judul karya ilmiah.

Kesimpulan karya ilmiah ini adalah: Pertama, Allah yang menyesal adalah Allah yang konsisten terhadap sifat dan karakter-Nya. Kedua, Allah yang menyesal adalah Allah yang harus dipahami melalui konteks firman Tuhan. Berdasarkan konteks Kejadian 6:6-7 Allah menyesal adalah Allah yang menyatakan pengakuanNya sebagai pencipta (6:6). Dan Mengungkapkan keputusan Allah (6:7). Ketiga, Allah menyesal adalah Allah yang tidak dapat menyangkal diri-Nya sebagai Allah yang ingin menyatakan bahwa Ia sangat berduka, tetapi harus menyatakan keadilannya sebagai Allah dan harus menghukum kejahatan manusia. Keempat, Allah menyesal adalah Allah yang menghendaki supaya manusia hidup dalam peraturan dan hukum-hukum yang Allah tetapkan dalam kehidupannya.
\end{abstract}

Kata Kunci: Tinjaun teologis, Allah menyesal, Kejadian 6:6-7

\footnotetext{
${ }^{1}$ Alumni Pascasarjana STT Jaffray Makassar 2013

${ }^{2}$ Dosen Pascasarjana STT Jaffray Makassar; Puket I Bagian Akademik STT Jaffray Makassar
} 


\section{PENDAHULUAN}

\section{Latar Belakang Masalah}

Begitu banyak konsekuensi yang terjadi ketika Allah mengungkapkan pernyataan-Nya dalam Kejadian 6:6-7 "Maka menyesallah TUHAN, bahwa Ia telah menjadikan manusia di bumi, dan hal itu memilukan hati-Nya. Berfirmanlah TUHAN: "Aku akan menghapuskan manusia yang telah Kuciptakan itu dari muka bumi, baik manusia maupun hewan dan binatang-binatang melata dan burungburung di udara, sebab Aku menyesal, bahwa Aku telah menjadikan mereka." Muncul berbagai spekulasi dan pertanyaan-pertanyaan, baik di kalangan teologi maupun jemaat Tuhan. Seperti, mengapa Allah menyesal menjadikan manusia sebagai ciptaan yang dibuat berdasarkaan gambar-Nya? Apakah Allah terbatas, apakah Allah tidak memiliki bingkai masa depan yang jelas akan akhir dunia dan kehidupan di mana Ia yang memulai di dalam-Nya? Jika Allah menyesal berarti Allah terbatas, Allah sama seperti manusia juga, Allah menyangkali sifat dasarNya sebagai Tuhan, sampai akhirnya bagaimana manusia yang diciptakan-Nya akan memandang diri-Nya sebagai Tuhan. Jika Allah tidak tahu akan kesudahan dari ciptaan-Nya, berarti Allah sama dengan omong kosong. Dengan berbagai macam argumentasi yang muncul atas sikap dan pernyataan Allah melalui Kejadian 6:6-7, maka sangat penting dijelaskan dan dimengerti apa maksud dan tujuan Allah atas penciptaan manusia dan semua makhluk hidup yang lainnya.

Allah sering dikatakan merasa sedih atau menyesal (Kej 6:6-7; Kel 32:14; I Sam 15:11; II Sam24:16; Yer 18:7,8; 26:13,19; Yun 3:10). Namun demikian, perikop-perikop lain menegaskan bahwa Allah tidak pernah menyesal dan berubah pikiran (bdg. Bil 23:19; I Sam 15:29; Yer 4:28; Maz 132:11). Bagian-bagian ini banyak memberikan tanggapan yang dilihat dari sudut pandang manusia atau perasaan manusia. Allah menyesal sepertinya menyatakan bahwa Dia tidak mengetahui mengenai tindakan manusia ciptaan-Nya. Seakan-akan menunjukkan bahwa Allah bukanlah Allah Yang Mahatahu. Allah seperti mematahkan argumentasi-Nya saat Ia mengatakan semua ciptaan-Nya adalah baik. Istilah 'Allah menyesal' merupakan bahasa anthropopathy. Kitab Suci sering menggunakan bahasa Anthropomorphism (bahasa yang menggambarkan Allah seakan-akan Ia adalah manusia) dan Anthropopathy (bahasa yang menggambarkan Allah dengan perasaan-perasaan manusia). ${ }^{3}$ Kata "menyesal" dalam ayat 6, diterjemahkan dari kata Ibrani "wayyinakhem" yang secara gramatikal memiliki pengertian bahwa Allah menyakiti atau menyedihkan hati-Nya.

\footnotetext{
${ }^{3}$ Budi Asali, "Allah Menyesal dan Allah Tidak Menyesal” golgotha_ministry; diakses tanggal 13 April 2013; tersedia di http://www.golgothaministry.org.
} 
Allah sangat menderita oleh karena dosa yang telah dan tengah diperbuat oleh umat-Nya. Dan kesedihan atau kesakitan yang dialami oleh Allah itu disebabkan oleh dosa manusia yang memperburuk dan merusakkan ciptaan-Nya (bdg. Yes 43:24b), membuat Ia menyesal. ${ }^{4}$ Segala sesuatu yang menjadikan Allah menyesal bukanlah karena perubahan sifat-Nya sebagai Allah, tetapi perubahan terjadi pada manusia yang lebih memilih melakukan tindakan dosa dalam kehidupannya.

Dosa dalam bahasa Ibrani adalah khattat yang berarti meleset dari tanda sasaran yang ditentukan atau menyimpang dari jalan. ${ }^{5}$ Bukan hanya sekedar kejahatan yang kita lakukan, melainkan suatu keadaan yang membelenggu kita, dosa adalah penyimpangan pribadi yang disengaja dari suatu norma, yang akhirnya ditujukan kepada Allah. ${ }^{9}$ Dosa merupakan penyakit moral yang luas sekali yang mempengaruhi umat manusia. Dosa terdiri dari perbuatan, perkataan, pikiran atau khayalan apa pun yang tidak seturut dengan pikiran dan hukum Allah. Penyimpangan sedikit saja, baik yang kelihatan maupun yang tidak kelihatan, dari kehendak dan karakter Allah yang dinyatakan adalah dosa. ${ }^{8}$ Ketika dosa masuk ke dalam dunia, manusia mulai berbuat sekehendak hatinya. Sekarang semua orang adalah orang-orang yang berdosa, tidak hanya sekedar meniru-niru, tetapi sudah menjadi naturnya. ${ }^{9}$ Dosa semakin lama semakin luas dan mendalam, awalnya adalah pembunuhan Habel oleh Kain (Kej 4:7), keturunan-keturunan Kain hidup dengan memisahkan diri dari Allah, menentang Allah sebagai pencipta dengan kejahatannya (Kej 4:23-24). Kejahatan dan dosa manusia semakin terlihat jelas dalam pasal 6. Manusia semakin berbuat sekehendak hatinya (6:2), bahkan tingkah lakunya hanya berbuahkan kejahatan. Akhirnya, Allah mengungkapkan bahwa Ia menyesal telah menjadikan manusia di bumi (Kej 6:6). Melalui ungkapan tersebut, sepertinya mengatakan bahwa Allah berubah dalam menentukan manusia sebagai makhluk yang diciptakan menurut gambaran-Nya, bahkan yang telah diberikan kuasa untuk menaklukkan bumi (Kej 1:28). Sifat Allah yang tidak berubah (Mzm 102:26-28; Yes 14:24, Mal 3:6)

\footnotetext{
${ }^{4}$ Rudi Sirait, "kok Allah Menyesal,"Surabaya Kebenaran; diakses tanggal 5 Juli 2013; tersedia dihttp://www.surabayakebenaran.blogspot.com.

${ }^{5}$ Leland Ryken, James C. Wilhoit dan Tremper Longman III, Kamus Gambaran Alkitab (Surabaya: Penerbit Momentum, 2011), 258.

${ }^{6}$ Leon Morris, Teologi Perjanjian Baru (Malang: Gandum Mas, 2001), 74.

${ }^{7}$ William Dyrness, Tema-tema Dalam Teologi Perjanjian Lama (Malang: Gandum Mas, 2001), 88.

${ }^{8}$ J.C. Ryle, Aspek-aspek Kekudusan (Surabaya: Penerbit Momentum, 2003), 1-2.

9 John Benton, dan John Peet, Kekayaan Kasih Karunia Allah (Surabaya: Penerbit Momentum, 2003), 36.
} 
seakan menyangkali perkataan-Nya sendiri dengan mengatakan bahwa Ia menyesal menjadikan manusia (bdg. Kel 32:14; Mzm 106:45; Yun 3:10). Ungkapan penyesalan Allah juga dapat menyiratkan bahwa Ia salah perhitungan ketika menciptakan manusia, sehingga Ia tidak tahu apa yang menjadi masa depan mereka, hal ini tidak sejalan dengan sifat-Nya sebagai Allah Yang Mahatahu (lih. Yes 40:13-14; Mzm 139:1-4; Ibr 4:13), Allah seakan menunjukkan bahwa Ia tidak konsisten dengan perkataan "sangat baik" (Kej 1:31) yang telah diucapkan-Nya kepada seluruh ciptaan-Nya.

Tetapi, sebenarnya dalam hal manusia, perubahan terjadi karena kita adalah makhluk-makhluk yang telah terjatuh dan terpisah dari Allah. Pasti dimensi moral dari keragaman kemanusiaan ini paling jelas terindikasi dalam reaksi orang banyak kepada Tuhan Yesus Kristus. Satu minggu mereka meneriakkan, "Hosana! Diberkatilah Dia yang akan datang dalam nama Tuhan, Raja Israel!" Minggu berikutnya mereka berteriak, "Enyahkan Dia! Salibkan Dia!" Natur manusia tidak dapat diandalkan, tetapi Allah dapat disandari. Ia tidak mungkin berubah. Natur-Nya selalu sama. Kehendak-Nya tidak berubah-ubah. Tujuantujuan-Nya pasti. Allah adalah pegangan yang pasti dalam alam semesta yang terus bergolak dan semakin merosot ini. ${ }^{10}$ Perubahan yang terjadi bukan pada diri Allah, tetapi pada diri manusia. Karena manusia diciptakan dengan perangkat kehendak bebasnya, sehingga manusia memilih untuk berbuat sesuai dengan hatinya yang telah tercemar oleh dosa, manusia tidak memikirkan bagaimana Sang Pencipta yang berdukacita melihat karya-Nya berbuat sesuatu tanpa berkonsultasi dengan-Nya sebagai Allah.

Pernyataan Allah dengan mengatakan bahwa Ia menyesal, ini bukan menunjukkan bahwa Ia gagal dalam menetapkan tujuan-Nya bagi manusia. Menurut Philip Eveson, doktrin kerusakan total mengajarkan, bahwa sebagai akibat pemberontakan manusia yang besar, di setiap bagian keputusannya itu telah dipengaruhi oleh dosa. Kehendak manusia, proses pikiran dan emosi telah terkontaminasi oleh dosa. ${ }^{l}$ Ungkapan Allah yang kontradiktif dengan tujuan semula penciptaan itu, menunjukkan bahwa Ia tidak dapat menyangkal diri-Nya yang begitu mengasihi manusia (Kej 6:8), sehingga dengan melihat kejahatan yang mereka lakukan membuat Allah berdukacita dan untuk itu Dia menyesal karena manusia memilih untuk menentang-Nya.

Dengan dosanya membuat Allah berdukacita. Ia berdukacita oleh karena manusia tidak bertobat kepada-Nya dan mencari Dia dalam

\footnotetext{
${ }^{10}$ James Montgomery Boice, Dasar-dasar Iman Kristen (Surabaya: Penerbit Momentum, 2011), 151-152.

${ }^{11}$ Philip Eveson, The Book of Origins (England: Evangelical Press, 2009), 155.
} 
hidupnya. ${ }^{12}$ Manusia yang telah mengalami perubahan, mereka telah menjalankan mandat kekuasaan yang Allah tugaskan, tetapi bukan dengan tunduk kepada-Nya, melainkan dengan kemanusiaannya yang arogan. Allah tidak berubah saat Ia mengatakan bahwa Ia menyesal menjadikan manusia dan memutuskan menghapuskan manusia dari dunia (Kej 6:6-7). Berkhof mengatakan, karena pengetahuan dan rencana-Nya, prinsip-prinsip moral dan tindakan-Nya tetap untuk selamanya. ${ }^{13}$ Penyesalan Allah itu bukanlah menunjukkan kegagalan Allah sebagai Tuhan yang mutlak dan tidak berubah dalam keputusanNya, bukan pula karena Ia berubah dalam ketetapan-Nya, manusialah yang berubah dan telah gagal memenuhi hukum dan perintah Allah yang Dia sampaikan.

Allah menyesal bukan karena Ia berubah dan gagal, tapi manusialah yang telah berbalik dari jalan-Nya. Allah tetap konsisten dalam hal, Ia menciptakan manusia karena Ia ingin manusia terlibat dalam rencana-Nya, kebaikan dan kesempurnaan telah Allah tawarkan kepada manusia supaya dapat menyembah-Nya, memelihara semua perintah-Nya dan yang terutama adalah manusia harus memuliakan Allah. Allah tetap konsisten terhadap janji dan karakter-Nya, Allah tidak pernah berubah, namun manusialah yang berubah. Allah tahu bahwa manusia hanya mengikuti hatinya yang jahat (Kej 6:5,11-12), Ia menyesal karena Ia tahu bahwa manusia hanya ingin hidup dalam kebobrokan moral yang tragis, sehingga Allah memutuskan bahwa Ia harus memberikan hukuman bagi dosa dan kejahatan manusia.

Jadi, penulis ingin mengungkapkan dalam sebuah karya ilmiah mengenai "Tinjauan Teologis: Allah Menyesal Berdasarkan Perspektif Kitab Kejadian Pasal 6:6-7."

\section{Pokok Masalah}

Berdasarkan pemaparan latar belakang diatas, yang menjadi pokok masalah dari penulisan karya ilmiah ini, adalah sebagai berikut:

Pertama, bagaimana eksposisi mengenai makna Allah menyesal berdasarkan persepektif kitab Kejadian 6:6-7?

Kedua, apa makna implikasi teologis tentang Allah menyesal berdasarkan persepektif kitab Kejadian 6:6-7? Ketiga, apa makna implikasi praktis tentang Allah menyesal berdasarkan kitab Kejadian $6: 6-7$ ?

\footnotetext{
${ }^{12}$ F.L. Bakker, Sejarah Kerajaan Allah: Jilid I/l (Jakarta: BPK Gunung Mulia, 1978), 56.

${ }^{13}$ Louis Berkhof, Teologi Sistematika: Doktrin Allah (Surabaya: Penerbit Momentum, 2010), 93.
} 


\section{Tujuan Penulisan}

Adapun yang menjadi tujuan dari penulisan karya ilmiah ini, adalah sebagai berikut:

Pertama, untuk menjelaskan makna Allah menyesal melalui pemaparan eksposisi nas di dalam kitab Kejadian 6:6-7, supaya dapat menghasilkan kerangka pemahaman yang benar tentang Allah sebagai Pencipta.

Kedua, untuk mendapatkan pemahaman yang benar mengenai Allah menyesal berdasarkan penjelasan implikasi teologis.

Ketiga, supaya orang percaya dapat mengerti makna mengenai Allah menyesal dalam kitab Kejadian 6:6-7 yang dijabarkan dalam implikasi praktis.

\section{Metodologi Eksposisi}

Penulisan karya ilmiah ini menggunakan metodologi eksposisi, dengan menggunakan prinsip-prinsip hermeneutika, yaitu dengan kajian eksegesis Alkitab mengenai Allah menyesal berdasarkan Kejadian 6:6-7 dan melalui penelitian kualitatif, yaitu dengan penggunaan buku-buku di perpustakaan yang berkaitan dengan konsep judul karya ilmiah.

\section{Batasan Penulisan}

Penulisan karya ilmiah ini dibatasi hanya dengan mengkaji mengenai makna Allah menyesal dalam persepektif kitab Kejadian 6:6-7.

\section{ManfaatPenulisan}

Adapun yang menjadi manfaat penulisan karya ilmiah ini adalah, sebagai berikut:

Pertama, supaya orang Kristen pada masa kini memahami tentang makna yang benar tentang Allah menyesal melalui tinjauan studi biblika berdasarkan persepektif Alkitab yang benar.

Kedua, supaya orang Kristen pada masa kini dapat memahami bahwa setiap tindakan dosa bertentangan dengan keberadaan Allah. Karena kejahatan manusia maka Allah merasa menyesal, bukan karena Dia gagal dalam rencana-Nya tetapi karena tidak dapat menyangkali diri-Nya yang mengasihi manusia. 


\section{ANALISIS KATA}

\section{Analisis ayat 6}

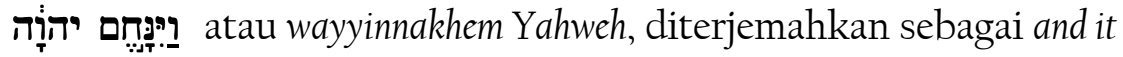
repented the LORD, yang dalam bahasa Indonesia berarti "maka menyesallah TUHAN." Berasal dari kata "nakham", kata wayyinnakhem menggunakan kata penghubung wa- dan memiliki bentuk kata kerja niphal imperfek orang ketiga tunggal maskulin, serta יזָi: atau Yahweh/Yehova, menunjuk kepada nama Allah, seperti yang terdapat dalam Kejadian 2:4, “..Ketika TUHAN Allah..” Yahweh atau Yehova ialah Allah perjanjian Israel yang berkepribadian, yang pada saat bersamaan merupakan Allah atas langit dan bumi. Nama ini mengandung eksistensi abadi Sang Pencipta segala sesuatu yang ada. ${ }^{14}$

Ada beberapa pengertian yang menjelaskan kata nakham dalam ayat 6 ini, antara lain: akan menyesal, tergerak pada belas kasihan, memiliki belas kasihan, akan menyesal, menyesali, berdukacita, bertobat, menenangkan diri, dihibur, menenangkan diri, memiliki penyesalan, perubahan hati (membiarkan diri untuk) menyesal. ${ }^{15}$ Ungkapan tentang nakham juga terdapat dalam Keluaran 32:14 “.. dan menyesallah..”, 2 Sam. 24:16 “.. maka menyesallah..," atau Yeremia 18:8 "..maka menyesallah..."

Kata menyesal itu dapat diterjemahkan dengan kata lain yang lebih tepat... apa yang dikehendaki oleh Allah ternyata tidak terlaksana, hal itu tidak menyenangkan dan menghibur-Nya. Allah tidak menghendaki siapa pun berbuat dosa, namun tatkala manusia berbuat dosa maka dia menjadi nakham. ${ }^{16}$ Jadi, karena kejahatan manusia, sehingga Allah berdukacita, yang awalnya Allah menghendaki keteraturan dan kebaikan bagi kehidupan manusia, tetapi telah dirusak oleh manusia pula, dengan perbuatan dosa mereka.

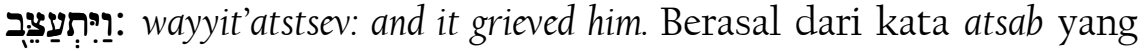
diterjemahkan sebagai to feel grieved, to be vexed, yang dalam bahasa Indonesia berarti memilukan. Wayyit'atstsev memiliki bentuk kata kerja hithpael imperfek orang ketiga tunggal maskulin, dengan wa- dipakai sebagai kata penghubung. Atsab dalam pengertian yang negatif adalah berhubungan dengan perasaan khawatir, rasa sakit dan kemarahan.

\footnotetext{
${ }^{14}$ Charles F. Pfeiffer dan Everett F. Harisson, Tafsiran Alkitab Wycliffe Volume 1 Perjanjian Lama: Kejadian-Ester (Malang: Gandum Mas, 2004), 31.

15 wayyinnakhem bentuk kata kerja niphal imperfek orang ketiga tunggal maskulin dari nakham (BMG Morphology, Word Analysis, s.v. "nakham” In Bible Works Version 7)

${ }^{16}$ Sarapan Pagi Biblika, "Bible Yang Meragukan: Alkitab Itu Palsu”; diakses tanggal 12 Februari 2013; tersedia di http.//www.sarapanpagi.org/bible-yangmeragukan-vt843-20.html
} 
Dalam beberapa pengertian penggunaan kata memilukan berarti menjengkelkan/tidak menyenangkan, berduka, sakit hati, membuat, menyesal, mengganggu, kesal, ibadah, atau merebut. ${ }^{17}$ Jadi, penggunaan kata memilukan di ayat 6 adalah penjelasan yang menggambarkan keadaan perasaan Allah yang terganggu dengan pemberontakan yang dilakukan manusia terhadap-Nya dan karenanya Ia menjadi sangat berduka.

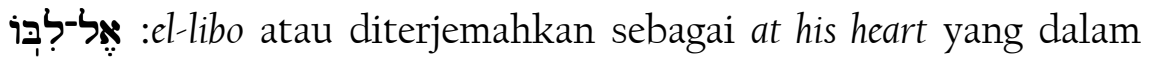
bahasa Indonesia diterjemahkan sebagai hati-Nya. אל atau el-merupakan

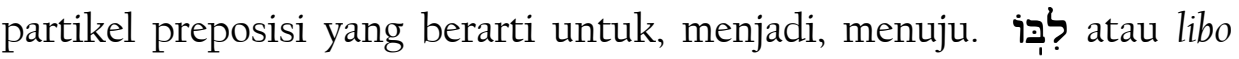
berasal dari kata leb (labe) yang di terjemahkan sebagai at his heart, yang dalam bahasa Indonesia berarti hati-Nya. Libo merupakan bentuk kata benda umum tunggal maskulin dengan akhiran ganti orang ketiga tunggal maskulin. ${ }^{18}$

Variasi lain dari arti leb antara lain batin manusia, pikiran, keinginan, hati, memahami, bagian dalam, tengah (dari sesuatu), jantung (manusia), jiwa, hati (manusia), pikiran, pengetahuan, pemikiran, refleksi, memori, kemiringan, resolusi, penentuan (kehendak), hati nurani, jantung (karakter moral), sebagai pusat selera, sebagai pusat dari emosi dan nafsu, sebagai pusat keberanian. Jadi, hati-Nya dalam ayat 6 berbicara tentang pusat dari perasaan dan pikiran yang tertuju kepada Allah tentang situasi hati-Nya yang melihat keberadaan manusia yang tidak sesuai dengan rencana yang telah dirancangkan-Nya.

\section{Analisis ayat 7}

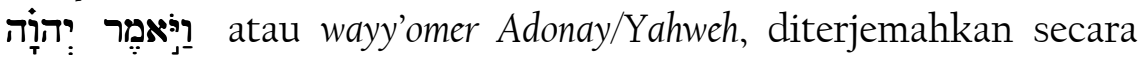
harfiah and the LORD said dan dalam pengertian bahasa Indonesia berarti "berfirmanlah TUHAN." Wayy'omer berasal dari kata amar, dengan ! (we-) sebagai partikel penghubung dan אמר bentuk kata kerja qal imperfek orang ketiga tunggal maskulin. Pengertian lain yang diterjemahkan untuk "berfirmanlah" yaitu mengatakan, berbicara, mengucapkan, (Qal) mengatakan, untuk menjawab, mengatakan dalam hati seseorang, untuk berpikir, untuk perintah, untuk berjanji, berniat. ${ }^{19}$ אמְמֶָ atau emekhe

${ }^{17}$ Wayyit'atstsev memiliki bentuk kata kerja hithpael imperfek orang ketiga tunggal maskulin dari kata atsab (BMG Morphology, Word Analysis, s.v. "atsab" In Bible Works Version 7).

${ }^{18}$ Libo merupakan bentuk kata benda umum tunggal maskulin dengan akhiran ganti orang ketiga tunggal maskulin (BMG Morphology, Word Analysis, s.v. "libo" In Bible Works Version 7).

אמר bentuk kata kerja qal imperfek orang ketiga tunggal maskulin dari kata amar (BMG Morphology, Word Analysis, s.v. "amar" In Bible Works Version 7). 
berasal dari kata machah, diterjemahkan sebagai I will destroy yang berarti "Aku akan menghapuskan", pengertian lain juga sebagai melenyapkan atau memusnahkan. ${ }^{20}$ Emekhe adalah bentuk kata kerja qal imperfek orang pertama tunggal. Tuhan sendiri yang berfirman bahwa Ia akan menghapuskan atau memusnahkan manusia yang diciptakan-Nya karena telah hidup dalam keadaan yang selalu menghasilkan perbuatan dosa.

a atau asyer-bara'ti, diterjemahkan sebgai whom I have created dan dalam pengertian bahasa Indonesia yaitu "yang telah Kuciptakan itu." Asyer sebagai kata penyerta berarti yang, bara'ti memiliki akar kata פּר (bara) dengan kata kerja qal perfek orang pertama tunggal, dengan pengertian membuat atau membentuk (menjadikan dari yang tidak ada menjadi ada). ${ }^{21}$ Istilah bara dalam bentuk qal dapat dijelaskan juga dengan arti lainnya yaitu untuk membentuk, membuat (selalu dengan Tuhan sebagai subjek): langit dan bumi, manusia individu, dari kondisi dan keadaan yang baru. Istilah bara digunakan secara khusus mengenai karya penciptaan Allah dan tidak pernah dipakai dengan manusia sebagai subjek. ${ }^{22}$ Kata ini menggambarkan pekerjaan yang tidak ada kesamaannya dengan pekerjaan manusia dan tidak dapat diterjemahkan dengan istilah seperti "membuat" atau "membangun". Dengan demikian hal ini melukiskan jenis pekerjaan yang hanya dapat dilakukan oleh Allah saja. Hanya Allah yang menciptakan, sebagaimana hanya Allah yang dapat menyelamatkan. ${ }^{23}$

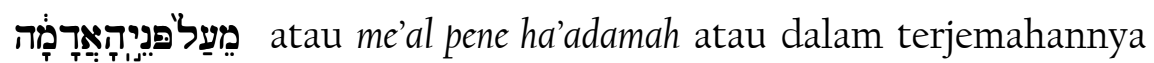
from the face of the earth serta dalam bahasa Indonesia berarti "dari muka bumi." "פַעַ (me'al) merupakan partikel penghubung dengan beberapa pengertian yaitu dari, keluar, dari oleh, dengan alasan, karena, pada atau

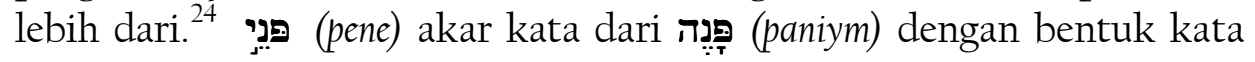
benda yang digunakan dalam bentuk jamak. Kata pene 'muka' memunyai

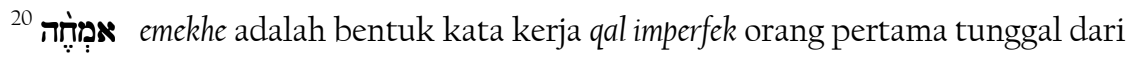
kata machah (BMG Morphology, Word Analysis, s.v. "emekhe” In Bible Works Version 7).

ברא bara adalah kata kerja qal perfek orang pertama tunggal (BMG Morphology, Word Analysis, s.v. "bara" In Bible Works Version 7).

${ }^{22}$ D. L. Baker, S.M. Siahaan, A. A Sitompul, Pengantar Bahasa Ibrani (Jakarta: BPK Gunung Mulia, 2010.), 83.

${ }^{23}$ W.S Lasor, D.A Hubbard dan F.W Bush, Pengantar Perjanjin Lama l: Taurat dan Sejarah (Jakarta: BPK Gunung Mulia, 1993), 122.

24 מֵַעל me'al merupakan partikel penghubung (BMG Morphology, Word Analysis, s.v. "me'al" In Bible Works Version 7). 
beberapa arti, termasuk 'wajah,' 'hadapan,' dan 'permukaan. (ha'adamah) dengan $\mathbf{n}$ (ha-) sebagai awalan penentu dengan arti itu, ini, yang. אִדָמָה (adamah) bentuk kata benda tunggal feminin, dengan beberapa variasi arti antara lain tanah, tanah (seperti yang umum, rezeki digarap, menghasilkan), sepotong tanah, sebidang tanah tertentu, hakekat bumi (untuk membangun atau membangun), tanah yang terlihat sebagai permukaan bumi, tanah, wilayah, negara, seluruh yang dihuni di bumi. ${ }^{26}$

נִחמְמִתִי atau nakhametti yang berarti for it repenteth me diterjemahkan dengan "sebab Aku menyesal." Bentuk kata kerja niphal perfek orang pertama tunggal. Kata nakhametti berasal dari kata nakham yang menghubungkan tentang perubahan dari hati atau watak, perubahan pikiran, perubahan tujuan, atau penekanan pada perubahan perilaku seseorang. Dalam contoh yang lainnya, Tuhan mengubah pikiran-Nya: dengan jelas, Dia berubah ketika manusia berubah dengan membuat pilihan yang benar, tapi Dia tidak dapat mengubah sikap-Nya terhadap kejahatan ketika manusia terus berada di jalan yang salah. ${ }^{27}$

עִשִׁיתחם atau asitim: that I have made them atau dalam arti bahasa Indonesia "bahwa Aku telah menjadikan mereka." Asitim memiliki bentuk kata kerja qal perfek orang pertama tunggal dengan akhiran ganti orang ketiga jamak maskulin. Asitim berasal dari akar kata asa yang memiliki beberapa arti yaitu melakukan, menjadikan, pembuatan, bekerja, menghasilkan, atau bertindak dengan efek. ${ }^{28}$ Jadi, pernyataan ini menunjuk kepada seluruh ciptaan yang telah dijadikan oleh Allah Sang Pencipta (Kej. 3:21).

\section{Makna Konteks Allah Menyesal Kejadian Pasal 6:6-7}

Allah Yang Menyesal Menyatakan Pengakuan-Nya Sebagai Pencipta (6:6)

Dalam ayat 6, dikatakan "Maka menyesallah TUHAN, bahwa Ia telah menjadikan manusia di bumi, dan hal itu memilukan hati-Nya." Ungkapan ini dapat dikatakan sebagai pengakuan Allah secara pribadi sebagai Pencipta, atas kejahatan manusia yang sudah melewati batas.

${ }^{25}$ D. L. Baker, S.M. Siahaan, A. A. Sitompul, Pengantar Bahasa Ibrani Jakarta: BPK Gunung Mulia, 2010.), 85.

אִדָמָה adamah adalah bentuk kata benda tunggal feminin (BMG Morphology, Word Analysis, s.v. "adamah" In Bible Works Version 7).

${ }^{27}$ Expository Dictionary of the Old Testament, s.v. "repent."

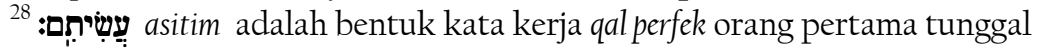
dengan akhiran ganti orang ketiga jamak maskulin (BMG Morphology, Word Analysis, s.v. "asitim " In Bible Works Version 7). 
Kadang-kadang Tuhan yang menyesal dari rencana untuk mendisiplinkan ciptaan-Nya. Allah biasanya berubah pikiran dan menyesal dari tindakannya karena syafaat manusia dan pertobatan dari perbuatan jahatnya. Dalam hal demikian, Tuhan bertobat atau berubah pikiran, untuk membawa perubahan rencana. Sekali lagi, bagaimanapun, Tuhan tetap setia kepada kebenaran-Nya yang absolut dalam kaitannya untuk dan dengan manusia. Bagian lain merujuk untuk mengubah (dalam sikap manusia). Ketika manusia tidak bertobat dari kejahatannya, ia memilih pemberontakan (Yer 8:6). ${ }^{29}$

Allah mengakui penyesalan-Nya akan keberadaan manusia yang selalu berbuat jahat dan hatinya lebih terarah untuk berbuat kejahatan (ay.5), sehingga hal ini memilukan hati Allah yang dari awal merencanakan kebaikan bagi manusia. Walter Lempp berpendapat, Allah terharu, iba hati-Nya oleh karena keadaan buruk ciptaan-Nya. Allah menderita di bawah dosa dan disebabkan dosa manusia yang memburukkan dan merusakkan ciptaan-Nya. ${ }^{30}$ Semua maksud dan rencana Allah telah gagal untuk menghasilkan buah yang berharga sebagaimana yang Ia harapkan, sebab dicegah oleh manusia berdosa. Allah mengalami kepedihan yang menusuk hati-Nya menyaksikan kemerosotan moral tragis yang dihasilkan dosa. Pekerjaan tangan-Nya telah dicemarkan dan dihancurkan. ${ }^{31}$

Jadi, Allah sangat berdukacita ketika menyaksikan manusia dengan kebobrokan moral dan tenggelam di dalamnya, Allah mengetahui setiap rancangan-Nya bagi manusia, sehingga melalui hal itu Allah mengungkapkan bahwa ia menyesal bukan karena Ia tidak mengetahui apa yang akan terjadi dalam kehidupan manusia, tetapi Ia menyesal karena manusia tidak mampu menjaga kesinambungan karya kebaikan yang diberikan-Nya kepada manusia.

\section{Mengungkapkan Keputusan Allah (6:7)}

Allah harus menghukum orang yang berdosa, oleh karena Ia, Sang Kudus tidak dapat melihat dosa, tetapi hukuman tidak diberikan oleh karena didorong nafsu mau menghukum. Ia berdukacita karena manusia tidak bertobat dan mencari Dia dalam hidup-Nya. ${ }^{32}$ Keputusan Allah

\footnotetext{
${ }^{29}$ Expository Dictionary of the Old Testament, s.v. "repent."

${ }^{30}$ Walter Lempp, Tafsiran Alkitab: Kitab Kejadian Pasal 5:1-12:3 (Jakarta: BPK Gunung Mulia, 1994), 66.

${ }^{31}$ Charles F. Pfeiffer dan Everett F. Harisson, Tafsiran Alkitab Wycliffe Volume 1 Perjanjian Lama: Kejadian-Ester (Malang: Gandum Mas, 2004), 52.

${ }^{32}$ F.L. Bakker, Sejarah Kerajaan Allah Jilid 1 Perjanjian Lama (Jakarta: BPK Gunung Mulia, 1982), 56.
} 
untuk menghukum manusia atas dosa mereka, adalah seruan yang menggambarkan bagaimana kesedihan Allah akan perbuatan manusia yang telah terus-menerus menyakiti hati-Nya (Kej. 6:11-12).

Murka Allah tidaklah sewenang-wenang, seolah-olah untuk suatu masalah kecil atau mengikuti perubahan pikiran-Nya sendiri dengan tiba-tiba Allah berpaling melawan mereka yang sebelumnya dikasihi dan perkenan.Sebaliknya murka adalah perlawanan Allah yangkonsisten dan tidak pernah mundur terhadap dosa dan kejahatan. ${ }^{33}$ Mengucapkan pertimbangan hati Allah sebagai keputusan agung. Sebagaimana kejahatan manusia adalah radikal (tak terbatas kepada dagingnya) dan universal (tak terbatas luasnya), demikian pula hukuman Allah adalah radikal dan universal. Bahkan selain dari manusia, akan kena hukum juga seluruh lingkungan binatang yang bernapas, yang hidup besertanya. Seluruh wilayah manusia yang jahat itu terkena hukuman Allah.Dosa manusia bukanlah hanya pembinasaan masyarakat manusia, melainkan juga mempengaruhi seluruh ciptaan. Sehingga Allah dengan keputusanNya dan seruan yang menyatakan "Sebab Aku menyesal, bahwa Aku telah menjadikan mereka." Sekali lagi dinyatakan segala kesedihan, kekhawatiran, dan kekecewaan hati Allah atas pemalsuan dan terbaliknya ciptaan, tetapi juga kegusaran dan kemarahan-Nya. ${ }^{34}$

Jadi, Allah telah mengungkapkan keputusan dan bahwa keputusan itu telah mencapai titik akhir untuk mengakhiri segala yang hidup, karena manusia telah menjalankan hidup yang rusak di bumi dengan kekerasan. Dampak hukuman yang terjadi diberikan kepada semua lapisan makhluk hidup yang ada di bumi. Allah tidak pernah berkompromi dengan dosa, walaupun Allah menciptakan manusia dan segala yang hidup dengan awal yang baik, namun Ia juga tidak menghendaki ketika ciptaan-Nya menjalankan kehidupan yang rusak dan tidak sesuai dengan rencana yang dirancangkan-Nya bagi mereka, sehingga semuanya pun harus diakhiri dengan keputusan penghukuman secara universal.

\section{IMPLIKASI TEOLOGIS KEJADIAN PASAL 6:6-7}

\section{Allah Menyesal Menjadikan Manusia dan Segala Ciptaan-Nya (6:6)}

Dalam Kej 1:27, "Allah menciptakan manusia menurut gambar-Nya, diciptakan-Nya laki-laki dan perempuan." Di ayat 31, Allah pun mengatakan bahwa segala yang dijadikan-Nya itu sungguh amat baik.

\footnotetext{
${ }^{33}$ James Montgomery Boice, Dasar-dasar Iman Kristen (Surabaya: Penerbit Momentum, 2011), 277.

${ }^{34}$ Walter Lempp, Tafsiran Alkitab: Kitab Kejadian Pasal 5:1-12:3 (Jakarta: BPK Gunung Mulia, 1994), 66-67.
} 
Tidak terdapat kesalahan dan kerusakan pada saat Allah menciptakan semua ciptaan-Nya. Walter C. Kaiser, Jr. mengatakan keduanya samasama mendapat anugerah tertinggi yang diberikan kepada tatanan penciptaan, yaitu: gambar Allah. Manusia laki-laki dan perempuan sama-sama memperoleh tanda tertinggi yang belum pernah diberikan kepada ciptaan. ${ }^{35}$ Karena anugerahlah sehingga manusia dinyatakan sebagai jiplakan dari kebaikan yang diberikan Allah, manusia diciptakan dengan detail yang unik dan menarik, tidak hanya itu, Allah pun memberikan tanggung jawab besar kepada manusia untuk menjadi pemimpin yang berkuasa atas segala ciptaan yang lain, supaya tatanan itu berjalan dengan selaras sesuai yang direncanakan Allah.

Allah menyesal menjadikan manusia dan segala ciptaan-Nya, ungkapan menyesal itu dinyatakan dalam firman-Nya untuk membuat manusia mengerti bagaimana hati Allah ketika melihat manusia berbuat dosa terus menerus, menyesal bukan berarti bahwa Allah gagal dalam perbuatan-Nya. Allah menyesal karena manusia yang dijadikan-Nya tidak dapat menjalankan tanggung jawab yang telah diberikan kepada mereka. Manusia gagal karena lebih memilih suka untuk berbuat jahat, manusia gagal karena mereka tidak dapat menjadi mitra Allah dalam melakukan rancana-Nya. Jadi, karena dosa telah berkembang dan menjadi pusat dari kelakuan manusia, Allah pun menyatakan bahwa Ia menyesal telah menjadikan manusia, ciptaan tertinggi yang awalnya baik, namun karena kehendak hatinya adalah kejahatan, maka buah yang dihasilkannya pun adalah kejahatan semata-mata, yang pada akhirnya membawa manusia kepada kesudahannya, yaitu seruan tentang hukuman seluruh ciptaan.

\section{Allah Menyesal Melihat Kejahatan yang Memilukan Hati-Nya (6:5-6)}

Pada ayat 5 dikatakan, "bahwa kejahatan manusia besar di bumi dan segala kecenderungan hatinya membuahkan kejahatan sematamata", bermakna bahwa segala hal yang menjadi tujuan manusia itu adalah kejahatan semata-mata. Kejahatan itu telah terpola dengan baik dalam hati, pikiran serta perasaan manusia, sehingga secara totalitas, sifat dan tindakan manusia menghasilkan kejahatan yang sedemikian rupa. Hati adalah pusat intelek. Orang sadar (insaf) akan sesuatu di dalam hati mereka (bdg. Ul 8:5), berdoa dalam hati (I Sam 1:12-13), merencanakan sesuatu di dalam hati (Mzm 140:3), menyimpan kata-kata dalam hati (Ams 4:21), dan semua hal yang menyangkut pikiran manusia. Hati juga adalah pusat perasaan, hati yang marah (Ams 19:3), hati yang khawatir (Ams 12:25), hati yang menderita (Yer 4:19; Rm 9:2) hati yang

\footnotetext{
${ }^{35}$ Walter C. Kaiser, Jr., Teologi Perjanjian Lama (Malang: Gandum Mas, 2004), 104.
} 
adalah pusat perasaan adalah hati yang menyangkut tentang emosional manusia. Dan hati juga merupakan pusat kehendak manusia, penolakan (bdg. Kel 4:21), penerimaan (bdg. Yos 24:23; Mzm 21:2-3), keputusan (II Taw 6:7) dan mengarahkan hati kepada hukum-hukum Allah (Mzm 119:36) adalah semua hal yang berkaitan dengan kehendak seseorang. Jadi, jika hati yang menjadi pusat dari pengontrolan diri manusia terhadap sesuatu menjadi rusak, maka semua hal yang keluar dalam tindakan pun akan terpengaruh oleh kerusakan itu pula. Hati manusia yang telah dipenuhi oleh kejahatan dalam ayat 5, juga akan menolak menaati Allah dan hukum-hukum yang diperintahkan-Nya serta mengganti semua hal itu dengan keinginan mereka sendiri yang telah didasarkan pada kejahatan semata.

Ungkapan penyesalan Allah terjadi karena manusia telah melakukan berbagai macam kejahatan dan kejahatan itu telah merusak gambar Allah yang ada pada manusia. Kepiluan dan penyesalan Allah bukan tidak berdasar, penyesalan-Nya membuktikan bahwa Ia yang telah merencanakan kebaikan justru dirusakkan oleh manusia. Karena kerusakan itu pulalah, manusia semakin berbuat jahat dan tanpa kendali mengubah gambar kebaikan Allah menjadi hal yang memilukan hati Allah sebagai akibat dari perbuatannya.

\section{Allah Menyesal Menyatakan Konsistensi-Nya Sebagai Allah $(6: 3,8-9)$}

Allah menyesal adalah Allah yang menyatakan konsistensi-Nya sebagai Allah yang akan menjelaskan mengenai makna dari sifat dan karakter Allah dan dibahas menjadi dua bagian, antara lain:

\section{Konsistensi Terhadap Sifat-Nya Sebagai Allah (6:8-9)}

Kita tidak boleh berpikir bahwa mungkin Ia akan mengubah sikap-Nya terhadap dosa, sehingga Ia akan menggolongkan sesuatu yang sebelumnya dilarang menjadi diizinkan. Dosa akan selalu menjadi dosa karena itu didefinisikan sebagai apa pun yang melanggar atau tidak sesuai dengan hukum Allah yang adalah Allah yang tidak berubah. ${ }^{36}$ Dosa adalah suatu kejahatan moral. ${ }^{37}$ Allah adalah Allah yang kudus (bdg. Kel 15:11; Im 11:45; Yes 6:3; Mzm 30:5; Mat 6:9), kasih (bdg. Yoh. 3:16; 16:27; Rm 5:8), adil (bdg. Ul 32:4; Hak 5:10; Mzm 7:1l, 17; 19:9 ) dan segala sesuatu yang menyatakan sifat-Nya sebagai Allah yang benar.

\footnotetext{
${ }^{36}$ James Montgomery Boice, Dasar-Dasar Iman Kristen (Surabaya: Penerbit Momentum, 2011), 107.

${ }^{37}$ Louis Berkhof, Teologi Sistematika Volume 2: Doktrin Manusia (Jakarta: Lembaga Reformed Injili Indonesia, 1994), 108.
} 
Tidak ada sesuatu pun yang kita lakukan dapat membuat kekekalan Allah berubah. Dengan menyatakan bahwa Ia menyesal, telah membuktikan kepada manusia bahwa Ia adalah Allah yang konsisten terhadap sifat-sifat-Nya.

Penyesalan Allah selalu menunjuk kepada keadilan dan kasih-Nya. Allah yang sebagai hakim itu (band. Kej 16:5; I Sam 24:13; Mzm 7:9; 50:6; Yes 33:22) akan membalaskan kejahatan yang setimpal kepada umatNya. Allah tidak dapat kompromi dengan dosa karena Ia sendiri sebagai penuntut segala macam dosa - pembalas (band. Ul. 32:35, 41; Mzm. 94:1; Yes. 34:8, 35:4). Ia menciptakan manusia dalam keberadaan sungguh amat baik (Kej. 1:31). Tentunya, Allah mengharapkan manusia hidup secara baik dalam pandangan-Nya. Manusia diciptakan oleh Allah tanpa dosa, ekspektasinya supaya manusia tidak hidup dalam dosa. Dosa itulah yang dibenci oleh Allah. Dosa itulah yang membuat manusia terpisah dan menerima hukuman Allah. ${ }^{38}$

Allah konsisten, karena hukuman atas kejahatan harus diberikan (6:7,13). Walaupun Allah memerintahkan hukuman untuk menyatakan keadilan-Nya, di lain pihak Allah juga menyatakan tindakan-Nya menyelamatkan manusia dan ciptaan yang lain untuk memelihara kelangsungan ciptaan-Nya (6:18-20). Jadi, melalui Nuh Allah membuktikan bahwa Dia bertindak dengan adil, keselamatan dan berkat diberikan bagi manusia yang taat kepada Allah $(6: 8-9,18)$ dan sebaliknya, hukuman akan diberikan jika manusia terus melakukan dosa dengan menentang hukum-hukum Allah (6:17).

Allah menyesal karena Ia adalah kasih (bdg. Yoel 2:13; Mikha 7:18). Ia mengingat akan kasih karunia yang diberikan-Nya kepada manusia (6:8-9). Kasih Allah dapat didefinisikan sebagai kesempurnaan Allah yang dengannya Ia digerakkan secara kekal kepada komunikasi diri. Ia mengasihi makhluk-Nya yang memunyai rasio demi diri-Nya sendiri, atau untuk menyatakannya dengan cara yang lain. ${ }^{39}$ Karena kasih-Nya maka Ia memilih Nuh. Nuh adalah seorang yang benar dan tidak bercela di antara orang-orang sezamannya, ia hidup bergaul dengan Allah dan mendapat kasih karunia khusus di mata Tuhan (6:8-9). Ia berusaha untuk hidup jujur dan suci, memiliki iman yang benar dalam zaman yang penuh dengan kejahatan. Hal yang tidak mudah bagi kita untuk bisa hidup benar dalam zaman yang buruk dan penuh kejahatan. ${ }^{40}$

\footnotetext{
${ }^{38}$ Rudi Sirait, "Kok Allah Menyesal,"Surabaya Kebenaran; diakses tanggal 5 Juli 2013; tersedia di http://www.surabayakebenaran.blogspot.com.

${ }^{39}$ Louis Berkhof, Teologi Sistematika Volume 1: Doktrin Allah (Jakarta: Lembaga Reformed Injili Indonesia, 2010), 118.

${ }^{40}$ Ro, Woo Ho, Manusia Kepunyaan Allah: Yang Ditemukan Melalui Pembacaan Alkitab Volume 1 Perjanjian Lama (Tangerang: Yayaysan YASKI, 2009), 13.
} 


\section{Konsistensi Terhadap Rencana-Nya Sebagai Allah (6:18)}

Allah bukanlah sejenis entitas yang abstrak atau prinsip yang tidak berkepribadian, Ia adalah Allah yang mengambil bagian, peduli dan mampu membangun relasi antara diri-Nya dengan manusia, Ia rela membuka diri-Nya untuk dukacita dan kesedihan ketika menghadapi pengkhianatan dan penolakan dari umat manusia. ${ }^{41}$ Tujuan akhir Allah di sepanjang sejarah ialah menyatakan kemuliaan-Nya, ${ }^{42}$ maka tujuan Allah menciptakan manusia adalah untuk menyatakan kemuliaan-Nya. Tetapi ketika dosa hadir dalam kehidupan, manusia tidak lagi memikirkan akan tujuan penciptaan-Nya. Manusia hanya fokus kepada pemujaan dirinya sendiri, tanpa memandang kepada Allah yang empunya kehidupan.

Dengan semakin bertambah besarnya kejahatan manusia di bumi, Allah semakin berdukacita dan mulai mendesain sesuatu yang baru untuk kelangsungan hidup di bumi. Konsistensi Allah terhadap rencanaNya atas manusia, Ia buktikan melalui permulaan yang baru dari seorang yang benar, yaitu Nuh (Kej. 6:9; 7:1). Rencana Allah tidak berhenti hanya karena manusia berbuat kejahatan yang sudah melewati batas (bdg. Mzm. 33:11; Yes. 14:24; 46:9-10). Menurut Boice, menyesal berarti memperbaiki rencana tindakan seseorang, tetapi Allah tidak pernah melakukan demikian. Rencana-rencana-Nya dibuat berdasarkan pengetahuan yang sempurna, dan kuasa-Nya yang sempurna melihat kepada pencapaian semua itu. ${ }^{43}$

Allah menyesal karena melihat bagaimana bobroknya tingkah laku manusia, bukan berarti Ia tidak tahu bagaimana masa depan manusia. R. Soedarmo berkata, Ia mengenal segala sesuatu sebelum terjadi, karena Ia adalah Pencipta dari segala hal, maka Ia jugalah yang menciptakan segala perkembangan dan segala jalan dari segenap makhluk. ${ }^{44}$ Ketidak berubahan Allah berarti bahwa Allah selalu sama dalam keberadaan-Nya yanag kekal. Allah tidak berubah, sementara tidak ada bagian lain dari ciptaan-Nya yang tidak berubah. Allah juga tidak berubah dalam tujuantujuan atau rencana-rencana-Nya. ${ }^{45}$

Jadi, walaupun Allah menyatakan penyesalan-Nya melihat manusia yang terus berbuat jahat dan kekerasan di bumi, rencana Allah tetap berlangsung dan tidak terbatas hanya karena kejahatan yang

${ }^{41}$ Paul Copan, Memahami Allah Perjanjian Lama (Malang: Literatur SAAT, 2012), 41.

${ }^{42}$ John Piper, Jadikan Sekalian Bangsa Bersukacita: Supremasi Allah Dalam Misi

(Bandung: Lembaga Literatur Baptis, 2003), 351.

${ }^{43}$ James Montgomery Boice, Dasar-Dasar Iman Kristen (Surabaya: Penerbit Momentum, 2011), 155.

${ }^{44}$ R. Soedarmo, Ikhtisar Dogmatika (Jakarta: BPK Gunung Mulia, 2001), 112.

${ }^{45}$ James Montgomery Boice, Dasar-Dasar Iman Kristen (Surabaya: Penerbit Momentum, 2011), 151, 153. 
diperbuat oleh manusia. Allah memilih Nuh yang telah mampu menjaga standar hidup yang diharapkan Allah untuk melanjutkan rencana-Nya bagi kehidupan selanjutnya.

\section{Allah Menyesal Dengan Menyatakan Tindakan Penghukuman $(6: 7,13)$}

Ketika Allah menciptakan manusia, Ia menginginkan berkat untuk kehidupan mereka. Namun Tuhan berubah pikiran karena hati manusia yang jahat, ini tidak berarti bahwa Tuhan tidak mengetahui segala sesuatu dari awal. Ia tahu cukup baik apa yang akan terjadi. Tuhan telah menunjukkan kasih karunia kepada manusia selama ratusan tahun, tetapi manusia kembali berdosa lebih dan lebih lagi, hati mereka menjadi begitu jahat sehingga Tuhan harus mengubah pikiran-Nya, bukan untuk berkat, Ia harus memberikan penghakiman. ${ }^{46}$ Allah membelokkan respon-Nya kepada manusia, yang seharusnya berkat tetapi berubah menjadi hukuman karena kejahatan yang telah berakar dalam pribadinya.

Allah menyesal bukan karena Ia tidak konsisten, Ia menyesal karena itu adalah reaksi dari kebenaran-Nya terhadap kejahatan. Ketika Allah menghendaki supaya kita melakukan perbuatan baik, itu berarti bahwa Ia tidak bersikap acuh tak acuh terhadap cara hidup kita. ${ }^{47}$ Karena Allah telah menilik bumi dengan seksama dan mendapati bahwa manusia di bumi telah menjalankan kehidupan yang rusak, maka Allah berketetapan untuk menghapuskan ciptaan-Nya yang tidak taat. Kejahatan telah merenggut kehidupan ciptaan Allah, karena kejahatan timbul dari keinginan hati manusia yang berdosa ${ }^{48}$ karena keinginan hati yang membuahkan kejahatan itu pula yang mengantar manusia masuk pada penghukuman Allah.

Jadi, manusia telah melanggar hukum yang ditetapkan Allah, ia tidak dapat memenuhi sasaran standar rencana yang telah Allah tetapkan. Manusia tidak mampu menjaga moral standar yang diinginkan Allah, karena semua keinginan hatinya, sikap serta perbuatannya menghasilkan kejahatan semata, sehingga menghapuskan manusia dari bumi adalah ketetapan penghukuman akhir yang harus di realisasikan oleh Allah terhadap manusia dan seluruh ciptaan yang ada.

\footnotetext{
${ }^{46}$ R.E. Harlow, Start Of The Race: Studies In Genesis (Canada: Everyday Publication, Inc, 1987), 22.

${ }^{47}$ Leon Morris, Teologi Perjanjian Baru (Malang: Gandum Mas, 2001), 32.

${ }^{48}$ Ensiklopedia Alkitab Masa Kini: Jilid A-L (Jakarta: Yayasan Komunikasi Bina Kasih, 2007), 468
} 


\section{IMPLIKASI PRAKTIS ALLAH MENYESAL BERDASARKAN KEJADIAN 6:6-7}

Pernyataan dalam Kejadian 6:6-7 mengenai Allah menyesal merupakan keadaan yang mengharuskan setiap manusia secara khusus orang percaya untuk selalu waspada bahwa Allah menghendaki supaya mereka hidup dalam peraturan dan hukum-hukum yang Allah tetapkan dalam kehidupannya. Implikasi praktis tentang Allah menyesal berdasarkan Kejadian 6:6-7, sebagai berikut:

\section{Manusia Harus Hidup Menurut Gambaran Allah Yang Mulia}

Manusia ciptaan Allah jauh berbeda dengan makhluk-makhluk lainnya. Di samping memiliki roh seperti yang dimiliki malaikat, manusia pun memiki jiwa seperti yang dimiliki binatang (yang lebih rendah). ${ }^{49}$ Sejak permulaan penciptaan manusia Allah memiliki rancangan-Nya sendiri dalam membentuk manusia, Allah menciptakan manusia menjadi mahkluk yang mulia lebih dari ciptaan yang lain. Manusia bukan saja mahkota dari seluruh ciptaan Allah, tetapi juga objek khusus pemeliharaan Allah. Allah menciptakan manusia dengan memiliki kehendak, rasa dan keinginan. Semua hal itu diberikan Allah sebagai perangkat yang lengkap untuk menjadi alat kemuliaan-Nya.

Pratt mengatakan, di dalam arti yang paling luas, Adam dan Hawa menyerupai Allah di dalam setiap hal yang dimungkinkan bagi ciptaan yang terbatas. Mereka memang dibatasi oleh ruang dan waktu, tetapi pikiran, kehendak dan emosi mereka dipolakan menurut penciptanya. Bahkan karakter fisik dan kemampuan mereka merefleksikan rohani dan kuasa Allah. Namun, meski semua perspektif di atas memang penting, Musa menjelaskan gambar dan rupa Allah dengan menekankan tugas yang Allah berikan untuk kita jalankan di dunia ini. Segera setelah Allah menciptakan manusia, Allah memberi mereka suatu perintah khusus: "Allah memberkati mereka, lalu Allah berfirman kepada mereka: "Beranakcuculah dan bertambah banyak; penuhilah bumi dan taklukkanlah itu, berkuasalah atas ikan-ikan di laut dan burung-burung di udara dan atas segala binatang yang merayap di bumi"' (Kej. 1:28). ${ }^{50}$ Jadi, manusia diciptakan dengan memiliki kesatuan yang lengkap sehingga manusia dikatakan menjadi ciptaan yang paling mulia di antara ciptaan Allah yang lain. Jadi, selain mencitrakan gambaran yang mulia, manusia juga memiliki tanggung jawab yang tidak diberikan melalui

\footnotetext{
${ }^{49}$ Watchman Nee, Manusia Rohani Volume l (Surabaya: Yayasan Perpustakaan Injil Indonesia, 1999), 68.

${ }^{50}$ Richard L. Pratt, Dirancang Bagi Kemuliaan (Surabaya: Penerbit Momentum, 2002), 28.
} 
perintah secara khusus kepada makhluk yang lain. Sehingga, kembali Pratt ungkapkan, Allah memang tidak perlu menciptakan gambar dan rupa diri-Nya; sama sekali tidak sulit bagi-Nya untuk memenuhi dunia ini dengan hadirat-Nya. Namun, Ia memilih untuk menegakkan otoritasNya di atas bumi melalui cara-cara yang dapat dipahami oleh manusia. ${ }^{51}$

Menurut Hoekema, keterkaitan manusia dengan sesama menunjukkan bahwa setiap menusia tidak boleh melihat karuniakarunia yang dimilikinya sebagai jalan untuk meninggikan diri sendiri, melainkan sebagai sarana yang dengannya ia bisa memperkaya hidup orang lain. Ini berarti kita harus bersemangat untuk menolong sesama, memulihkan mereka dari penderitaan, memberikan apa yang mereka butuhkan, menanggung beban mereka, dan berbagi sukacita mereka. Ini berarti kita harus mengasihi sesama seperti diri sendiri. Ini berarti setiap manusia memiliki hak untuk diterima, untuk menjadi bagian dan untuk dikasihi oleh sesama. Ini berarti, dikasihi dan mengasihi merupakan aspek yang esensial. ${ }^{52}$ Manusia sebagai ciptaan Allah yang mulia adalah ciptaan Allah yang memiliki hak dan kewajiban yang sama. Dalam setiap aspek yang meliputi sosial, budaya, ekonomi, politik dan hukum, semua manusia memiliki hak yang sama tanpa terkecuali. Hal ini berarti manusia memiliki nilai yang sama di hadapan Allah. Untuk itu karena manusia merupakan gambar dan rupa Allah, maka manusia harus menyadari akan nilai dirinya yang berharga di hadapan Allah, dan harus menghargai dan menghormati dirinya dan juga orang lain yang samasama merupakan ciptaan Allah yang mulia.

\section{Manusia Tidak Dapat Membatalkan Rencana Allah}

Menurut Erickson, sifat rencana ilahi meliputi beberapa hal sebagai berikut: Pertama, rencana Allah sudah dibuat sejak kekelalan. Kedua, rencana Allah serta keputusan-keputusan yang terdapat di dalamnya sepenuhnya ditentukan oleh Allah sendiri. Ketiga, secara mendasar tujuan rencana Allah adalah kemuliaan-Nya. Keempat, rencana Allah meliputi segala sesuatu. Kelima, rencana Allah pasti terwujud. Keenam, rencana Allah lebih terkait dengan tindakan-tindakan-Nya ketimbang dengaan sifat-Nya. Rencana Allah berkaitan dengan keputusan-keputusan-Nya tentang apa yang akan Dia lakukan dan bukan dengan sifat-sifat pribadi-Nya. Ketujuh, rencana Allah terutama berkaitan dengan apa yang dilakukan oleh Allah sendiri yaitu mencipta, memelihara, memimpin dan menebus. ${ }^{53}$

\footnotetext{
${ }^{51}$ Ibid., 30.

${ }^{52}$ Anthony A. Hoekema, Manusia: Ciptaan Menurut Gambar Allah (Surabaya: Penerbit Momentum, 2003), 100.

${ }^{53}$ Millard J. Erickson, Teologi Kristen (Malang: Gandum Mas, 1999), 351-354.
} 
Menurut Thiessen, sekalipun Allah tidak berubah, namun seringkali cara-cara yang dipakai-Nya itu berubah. ${ }^{54}$ Allah adalah Mahatahu dan Ia telah menjadikan segala sesuatu didalam kemahatahuan-Nya. Allah tidak kaget dengan pemberontakan dan kejahatan yang ditimbulkan oleh hati manusia karena dosa. Karena Allah telah memiliki rencana yang ditetapkan-Nya sejak semula. Allah berdaulat untuk melakukan segala sesuatu, karena Allah adalah standar kebenaran yang absolut. Allah menyesal bukan suatu ungkapan yang membuktikan bahwa Allah tidak tahu manusia akan menentang kuasaNya. Tetapi Allah menyesal menyiratkan makna bahwa Allah telah begitu mengasihi manusia, menjadikannya serupa dengan Sang Pencipta, memiliki keinginan dan kemampuan dalam mengambil keputusan, namun di balik semua itu manusia lebih memilih kebanggaan pada dirinya dengan melakukan kejahatan, manusia menolak taat kepada Allah karena manusia melakukan rencana bagi dirinya sendiri tanpa peduli bahwa Allah memiliki rencana dan akhir yang sempurna bagi dirinya. Bandingkan dengan Keluaran 33:19, “.. Aku akan memberi kasih karunia kepada siapa yang Kuberi kasih karunia dan mengasihani siapa yang Kukasihani." Walaupun sepertinya Allah memberikan pertanyaan dalam hati manusia, Allah tidak berkewajiban menemukan jawaban hanya untuk memuaskan keingintahuan manusia. Pink katakan, Melalui ketidakacuhan-Nya untuk membela diri, Allah sedang menyatakan hak kedaulatan-Nya untuk dipercaya dan ditaati, apa pun kecurigaan yang muncul dalam pikiran manusia yang mungkin ditimbulkan oleh tindakan-Nya. Dalam keputusan-keputusan-Nya Dia tidak akan tunduk pada penilaian manusia. Ia berhak untuk melakukan apapun yang sedikit banyak mungkin mengganggu nilai-nilai manusia, dilihat dari sudut pandang manusia pun mungkin tindakan-Nya tampak berkontradiksi dengan nilai-nilai-Nya sendiri. Dan bila itu terjadi, Ia tidak berada dibawah penilaian manusia. Ia tidak wajib menjelaskannya. ${ }^{55}$ Jadi, walaupun manusia melakukan berbagai macam kejahatan dalam dunia, Allah tetap meneruskan rencana-Nya bagi dunia. Kejahatan manusia tidak dapat membatalkan rencana Allah.

\footnotetext{
${ }^{54}$ Henry C. Thiessen, Teologi Sistematika (Malang: Gandum Mas, 1992), 308.

${ }^{55}$ John M. Frame, Apologetika Bagi Kemuliaan Allah (Surabaya: Penerbit Momentum, 2009), 222-223.
} 
Menurut Boice, kita tidak dapat menyingkirkan Allah, bahkan melalui dosa. Semua yang kita lakukan adalah menukar satu hubungan dengan Allah untuk hubungan yang lain. Jika kita tidak menginginkan kasih dan anugerah Allah, kita akan mendapatkan murka Allah. Karena Allah tidak dapat melihat dengan toleran terhadap kejahatan. ${ }^{56}$

\section{Manusia Membutuhkan Anugerah Allah}

Segala yang hidup di dalam dunia ciptaan Allah terjadi dan berlangsung dengan keteraturan yang berada dalam kendali Sang Pencipta. Manusia ciptaan Allah membutuhkan anugerah Allah untuk terus bertahan dalam keteraturan dunia ini. Dengan anugerah dari Allah melalui kasih-Nya yang begitu sempurna, manusia dapat memperoleh berkat dan bertahan sampai saat ini. Ungkapan mengenai Allah menyesal dalam Kejadian 6:6-7, membuktikan manusia membutuhkan anugerah Allah yang akan dijabarkan sebagai berikut:

\section{Anugerah Keselamatan Bagi Dirinya}

Manusia tidak dapat menyelamatkan dirinya sendiri. Manusia adalah bagian dari rancangan Allah untuk kemuliaan-Nya. Allah mengetahui segala sesuatu yang ada dalam tatanan ciptaan-Nya. Allah pun telah memiliki alur-Nya sendiri dalam mempersiapkan segala hal yang kompleks untuk menuju kepada akhirnya yaitu keselamatan manusia. Ungkapan Allah menyesal merupakan bagian yang begitu ironis dalam sejarah peradaban manusia. Hal ini membuktikan bahwa keberadaan manusia sudah berada di luar batas yang Allah ijinkan untuk dilakukan oleh manusia. Boice mengatakan bahwa anugerah tidak mengurangi murka; murka masih disimpan bagi orang-orang yang tidak bertobat. Tetapi, anugerah mengurangi keniscayaan setiap orang untuk mengalaminya. ${ }^{57}$ Keadaan manusia yang rusak dan pernyataan Allah yang ironis membuktikan bahwa sesungguhnya manusia membutuhkan keselamatan akan dirinya di hadapan Allah. Tindakan penyelamatan Allah terhadap keluarga Nuh menjadi bukti bahwa manusia tidak dapat menyelamatkan dirinya sendiri. Allah menghendaki kelangsungan hidup seluruh ciptaan-Nya, sehingga Ia juga yang menetapkan untuk menyelamatkan keluarga Nuh supaya dari keturunan Nuh lah manusia memulai peradaban yang baru lagi.

Jadi, Allah yang menyesal bukanlah Allah yang gagal dalam memenuhi rancangan bagi kemuliaan-Nya, Allah yang menyesal bukanlah Allah yang tidak mengetahui akan kelangsungan ciptaan-Nya,

\footnotetext{
${ }^{56}$ James Montgomery Boice, Dasar-dasar Iman Kristen (Surabaya: Penerbit Momentum, 2011), 278.

${ }^{57}$ Ibid., 285.
} 
tetapi Allah yang menyesal adalah Allah yang ingin menyatakan diri-Nya terhadap manusia bahwa Dia adalah Allah yang berkuasa untuk mengatur segala sesuatu dibawah kendali-Nya.

\section{Anugerah Allah Dasar Hubungan Sesama Manusia}

Kejahatan dan kerusakan manusia dimuka bumi membuktikan bahwa tidak ada lagi yang baik dari tindakan manusia, terhadap diri sendiri dan juga terhadap sesamanya. Allah menyesal menjadi ungkapan yang menjelaskan bahwa tindakan manusia hanya memikirkan dirinya sendiri dan tanpa melakukan sesuatu yang baik bagi sesamanya. Manusia tidak dapat membangun relasi yang baik tetapi cenderung untuk melakukan kejahatan. Manusia tunduk kepada keinginan dosa, sehingga yang dipikirkan hanya diri sendiri, tanpa ada rasa perduli bagi sesamanya. Pada ayat 8-9, dikatakan bahwa Nuh adalah orang yang beroleh kasih karunia dan berkenan dihadapan Allah diantara orangorang sezamannya. Menurut Abraham Park, Nuh adalah pelita Allah di tengah zaman kegelapan dan kejahatan oleh dosa dan ayat ini juga menyatakan keadaan yang telah jatuh ke dalam dosa secara total sehingga tidak ada seorang pun yang saleh, kecuali Nuh dan keluarganya. ${ }^{58}$ Manusia tidak dapat mengasihi Allah sebagaimana Allah mengasihi dunia dan segala ciptaan-Nya yang ada didalamnya, manusia hanya melakukan apa yang mereka inginkan, dan semua keinginan manusia adalah kejahatan.

Allah menghendaki manusia ciptaan-Nya dapat saling mengasihi di dalam dunia ciptaan-Nya. Namun, kondisi yang terjadi justru sebaliknya, Allah menilik bumi dan memang sudah menjadi rusak karena manusia terus melakukan kekerasan (ay. 11-12). Karena di dalam diri-Nya yang terdalam Allah adalah kasih, maka ketika Ia membuat kita menurut gambar-Nya Ia memberi kita kapasitas untuk mengasihi. ${ }^{59}$

\section{Anugerah Bagi Seluruh Makhluk Hidup}

Ketika Allah memutuskan untuk memusnahkan segala yang hidup, Allah tetap berjanji untuk memelihara kelangsungan umat manusia, bahkan seluruh makhluk hidup dengan memerintahkan Nuh membawa setiap pasangnya ke dalam bahtera (ay.19). Di dalam Kejadian pasal 1, Alkitab menjelaskan bagaimana proses penciptaan alam semesta dan semua makhluk hidup yang ada di bumi. Allah menyatakan bahwa semua yang dia ciptakan dan selesaikan melalui firman-Nya adalah baik dan bahkan sangat baik. Tetapi, semua berubah saat manusia jatuh ke

\footnotetext{
${ }^{58}$ Abraham Park, Silsilah Di Kitab Kejadian (Jakarta: PT Gramedia Widiasarana Indonesia, 2010), 142-143.

${ }^{59}$ John Stott, Mengapa Saya Seorang Kristen (Bandung: Pionir Jaya, 2009), 61.
} 
dalam dosa (Kej 3), manusia tidak hanya mendatangkan penderitaan bagi dirinya, tetapi penderitaan juga berdampak kepada seluruh makhluk hidup lainnya.

Jika manusia diperintahkan hanya untuk berkuasa atas bumi, maka perintah ini akan dengan mudah dianggap sebagai undangan terbuka untuk melakukan eksploitasi yang tak bertanggung jawab terhadap sumber daya bumi. Tetapi, perintah mengusahakan dan memelihara Taman Eden menunjukkan selain menguasai, kita juga harus melayani dan melestarikan bumi. Tetapi manusia, yaitu kita, harus berkuasa atas alam dengan cara sedemikian rupa sehingga menjadi pelayannya juga. Kita harus memperhatikan pelestarian sumber daya alam dan memanfaatkannya sebaik mungkin. Kita harus mencegah erosi tanah, perusakan besar-besaran terhadap hutan, pemakaian energi yang tak bertanggung jawab, polusi sungai dan danau, dan polusi udara yang kita hirup. Kita harus menjadi pelayan untuk bumi dan semua yang ada didalamnya, dan untuk mendukung apa pun yang akan memberikan manfaat dan keindahan bumi ini demi kemuliaan Allah. ${ }^{60}$ Allah telah memberkati manusia dengan hikmat dan pengertian, walaupun manusia telah jatuh ke dalam dosa manusia masih tetap membawa gambar dan rupa Allah beserta dengan apa yang telah dianugerahkan kepadanya. Walaupun Allah menghukum manusia atas dosanya, Allah tetap memberikan anugerah berkat bagi manusia yang mau berusaha untuk memelihara sarana yang disediakan Allah dalam dunia. Untuk itu manusia harus sedapat mungkin memelihara dan mengusahakan yang terbaik bagi kelangsungan seluruh ciptaan.

\footnotetext{
${ }^{60}$ Anthony A. Hoekema, Manusia: Ciptaan Menurut Gambar Allah (Surabaya: Penerbit Momentum, 2003),102-103.
} 


\section{PENUTUP}

\section{Kesimpulan}

Pertama, Allah yang menyesal adalah Allah yang konsisten terhadap sifat dan karakter-Nya. Ketika Allah menciptakan manusia, Dia telah merancang semuanya dengan kebaikan, Dia memberkati manusia dengan segala sesuatu yang mereka dibutuhkan.

Kedua, Allah yang menyesal adalah Allah yang harus dipahami melalui konteks firman Tuhan. Kitab Kejadian adalah dasar dari semua penjelasan seluruh kitab yang ada dalam Firman Allah. Berdasarkan konteks Kejadian 6:6-7 Allah menyesal adalah Allah yang menyatakan pengakuan-Nya sebagai pencipta (6:6). Dan Mengungkapkan keputusan Allah (6:7).

Ketiga, Allah menyesal adalah Allah yang tidak dapat menyangkal diri-Nya sebagai Allah yang ingin menyatakan bahwa Ia sangat berduka, tetapi harus menyatakan keadilannya sebagai Allah dan harus menghukum kejahatan manusia. Allah menyesal menyatakan bahwa Ia adalah Allah yang berkuasa dan berdaulat dengan menyatakan bahwa Dialah yang telah menjadikan manusia dan segala ciptaan-Nya (6:6), Allah menyesal adalah Allah yang melihat kejahatan yang memilukan hati-Nya (6:6), Allah menyesal adalah Allah yang menyatakan konsistensi-Nya sebagai Allah (6:3, 8-9), yaitu: konsistensi terhadap sifat-Nya sebagai Allah (6:8-9) dan konsistensi terhadap rencana-Nya sebagai Allah (6:18). Dan Allah yang menyesal adalah Allah yang menyatakan tindakan penghukuman $(6: 7,13)$.

Keempat, Allah menyesal adalah Allah yang menghendaki supaya manusia hidup dalam peraturan dan hukum-hukum yang Allah tetapkan dalam kehidupannya. Ungkapan Allah menyesal membuktikan bahwa manusia membutuhkan anugerah Allah dalam hidupnya (8-9), ini menyatakan bahwa manusia membutuhkan keselamatan dari Allah,karena anugerah Allah maka manusia harus menyadari bahwa ia harus memiliki hubungan yang bertanggung jawab atas sesamanya $(6,8$ 9), dan juga karena anugerah Allah manusia harus memelihara semua ciptaan Allah sebagaimana Allah memelihara kehidupan dan kelangsungan seluruh tatanan alam semesta (18-20). 


\section{KEPUSTAKAAN}

\section{Alkitab}

Alkitab Penuntun Hidup Berkelimpahan, Cetakan Kedelapan. Malang: Gandum Mas dan Lembaga Alkitab Indonesia, 2004.

Alkitab Rainbow. Jakarta: Lembaga Alkitab Indonesia, 2008.

Kamus

Ensiklopedia Alkitab Masa Kini: Jilid A-L. Jakarta: Yayasan Komunikasi Bina Kasih, 2007.

Expository Dictionary of the Old Testament

Leland Ryken, James C. Wilhoit dan Tremper Longman III. Kamus Gambaran Alkitab. Surabaya: Penerbit Momentum, 2011.

Tim Penyusun Kamus Pusat Pembunaan dan Pengembangan Bahasa. Kamus Besar Bahasa Indonesia. Jakarta: Balai Pustaka, 1994.

Buku-buku

Baker, D.L, S.M. Siahaan, A. A Sitompul. Pengantar Bahasa Ibrani. Jakarta: BPK Gunung Mulia, 2010.

Bakker, F.L. Sejarah Kerajaan Allah: Jilid I/l. Jakarta: BPK Gunung Mulia, 1978.

Benton, John dan John Peet. Kekayaan Kasih Karunia Allah. Surabaya: Penerbit Momentum, 2003.

Berkhof, Louis. Teologi Sistematika: Doktrin Allah. Surabaya: Penerbit Momentum, 2010.

Boice, James Montgomery. Dasar-dasar Iman Kristen. Surabaya: Penerbit Momentum, 2011.

Bridges, Jerry. Hidup yang Berbuah. Bandung: Pionir Jaya, 2009.

Copan, Paul. Memahami Allah Perjanjian Lama. Malang: Literatur SAAT, 2012.

Dyrness, William. Tema-tema dalam Teologi Perjanjian Lama. Malang: Gandum Mas, 2001.

Frame, John M. Apologetika Bagi Kemuliaan Allah. Surabaya: Penerbit Momentum, 2009.

Geisler, Norman L. dan William E. Nix. A General Introduction to The Bible. Chicago: Moody Press, 1987.

Harlow, R.E. Start of The Race: Studies In Genesis. Canada: Everyday Publication, Inc, 1987. 
Hill, Andrew E. dan John H. Walton. Survei Perjanjian Lama. Malang: Gandum Mas, 1996.

Hoekema, Anthony A. Manusia: Ciptaan Menurut Gambar Allah. Surabaya: Penerbit Momentum, 2003.

Kaiser, Jr. Walter C. Jr. Teologi Perjanjian Lama. Malang: Gandum Mas, 2004.

Lasor, W.S, D.A Hubbard dan F.W Bush. Pengantar Perjanjin Lama 1: Taurat dan Sejarah. Jakarta: BPK Gunung Mulia, 1993.

Morris, Leon. Teologi Perjanjian Baru. Malang: Gandum Mas, 2001.

Nee, Watchman. Manusia Rohani Volume 1. Surabaya:Yayasan Perpustakaan Injil Indonesia, 1999.

Park, Abraham. Silsilah di Kitab Kejadian: Dilihat dari Sudut Pandang Penyelenggaraan Sejarah Penebusan. Jakarta: PT Gramedia Widiaasarana Indonesia, 2010.

Piper, John. Jadikan Sekalian Bangsa Bersukacita: Supremasi Allah Dalam Misi. Bandung: Lembaga Literatur Baptis, 2003.

Rumahlatu, Jerry. Hermeneutika Sepanjang Masa. CV. Cipta Varia Sarana, 2011.

Stott, John. Mengapa Saya Seorang Kristen. Bandung: Pionir Jaya, 2009.

Thiessen, Henry C. Teologi Sistematika. Malang: Gandum Mas, 1992.

\section{Artikel Online}

Asali, Budi. "Allah Menyesal dan Allah Tidak Menyesal" golgotha_ministry; diakses tanggal 13 April 2013; tersedia di http://www.golgothaministry.org.

"Bible Yang Meragukan," Sarapan Pagi Biblika: Alkitab Itu Palsu; diakses tanggal 8 November 2012; tersedia di http.//www.sarapanpagi.org/bible-yang-meragukan-vt843-20.html

Sirait, Rudy R. "kok Allah menyesal." Surabaya Kebenaran; Di akses tanggal; 29 Maret 2013; tersedia di http://surabayakebenaran.blogspot.com/2012/07/normal-0-falsefalse-false-in- $x$-none- $x$.html

\section{Disertasi}

Maiaweng, Peniel Cornelis Dominggus. "Studi EksplanatoriKonfirmatori Ajaran Tentang Allah Menyesal Berdasarkan Kitab Yunus Pasal 3-4 Diantara Para Pengerja Gereja Kemah Injil Indonesia Daerah Samarinda" (Semarang: Sekolah Tinggi Teologia Baptis Indonesia, 2011. 